\title{
4 \\ WHO WERE THE MISSIONARIES?
}

Until the early twentieth century, Christian missions to Aboriginal people mostly failed within only a few years. Oenpelli was part of a new generation of missions, scattered across northern and central Australia, to Aboriginal people who lived on Country and who had few dealings with Europeans so far.

These twentieth-century missions started as humanitarian ventures. Of course, there was always the intention to convert Aboriginal people to Christianity, but the assumption was that Aboriginal people could have no place in white Australia. At the turn of the century, much of white Australia expected that Aboriginal people were doomed to extinction. Missionaries hoped that perhaps, by their intervention, they might save some. But contact with white 'civilisation', they believed, was toxic to Aboriginal people. Enticing and attractive, but like the forbidden fruit of Eden, it would be their downfall. As Dyer himself wrote, 'civilisation spells their extinction'. ${ }^{1}$

Christian churches and mission organisations, therefore, looked for isolated places where they believed they could attract Aboriginal people to missions, shield them from other white Australians, develop Aboriginal people's skills in agriculture, and conduce them to 'settle down' and, most of all, to convert to Christianity. Many established missions on islands, ideal for their isolation. The Tiwi Islands missions and Milingimbi missions in the Top End are examples.

1 Annual Report Oenpelli 1928, NAA A431/1. 
Oenpelli, however, was not such an attractive location for mission organisations because it was too central and accessible. An island would be better. The Church Missionary Society, however, was convinced that the Arnhem Land escarpment was a sufficient natural 'fence' to keep Aboriginal people in and others out, and so seized the opportunity to establish a mission when Paddy Cahill's cattle station became available.

The humanitarian crisis for Aboriginal people in the Northern Territory was real. There were many massacres. In 1878, settlers shot and clubbed to death 17 Aboriginal people on the Daly River. Thirty were killed in another massacre on the Daly in 1884. About 100 Yolngu people were killed in a massacre between 1889 and 1896 near Milingimbi and, in 1903, 30 Alawa people were shot at Minyerri. ${ }^{2}$ There were other massacres and murders that went unrecorded by Europeans but are not forgotten by communities today. In addition to violence, sexually transmitted diseases, malaria, influenza and leprosy were major health problems. Estimates were that 60 per cent of the population had leprosy in some form. ${ }^{3}$

So the CMS work in north Australian missions began with explicit humanitarian intentions. The Bishop of North Queensland, Rev. Frodsham, spurred evangelicals to work in Arnhem Land in $1906 .{ }^{4}$ Frodsham called for missionaries of the so-called 'stronger race' to take action, constructing their mission in terms of humanitarian compassion, couched in racial hierarchies:

Missionary work then may be only smoothing the pillow of a dying race, but I think that if the Lord Jesus came to Australia he would be moved with great compassion for these poor outcastes, lying by the wayside, robbed of their land, wounded by the lust and passion of a stronger race. ${ }^{5}$

Aboriginal people, he thought, might not survive the coming of the 'stronger race', but that race should, at least, show compassion to those they had supposedly conquered, went his argument.

2 Centre for 21st Century Humanities, 'Colonial Massacres Map'.

3 Cole, From Mission to Church, 124.

4 Dewar, The 'Black War' in Arnhem Land, 9; Cole, A Short History of the C.M.S. Roper River Mission, 5.

5 Frodsham, Bishop of North Queensland in Clarke, Report of the Church Congress. 


\section{The Church Missionary Society}

The CMS was a product of the evangelical revivals in late eighteenth-century England. In 1799, a small band of evangelicals established their 'Society for Missions to Africa and the East', which later became the CMS. ${ }^{6}$ The CMS went wherever the British Empire went, sometimes preceding it and preparing the way (as in New Zealand). Its original founders had Botany Bay in mind for a mission field. Despite this, it did very little in Australia in the early nineteenth century. It operated only briefly in the 1830s at the Wellington Valley mission. The mission provided food and medical aid and was a refuge from violent settlers encroaching on Wiradjuri land. Missionaries started learning Wiradjuri and, with Wiradjuri co-translators, translated some scripture. But then the missionaries kidnapped Wiradjuri children, so the Wiradjuri left. When the missionaries began fighting each other, the station imploded, and the mission closed.

In 1892, Church Missionary Associations (CMAs) were established in New South Wales and Victoria, both independent of the 'Parent Society'. These sent Australian missionaries all over the world but also operated missions to the 'heathen' Aboriginal people of Victoria (Yelta, Lake Tyers and Lake Condah). ${ }^{7}$ In 1916 the associations came together to form the CMS of Australia and Tasmania (later simply 'CMS Australia'). Although CMS Australia remained autonomous, the Australians considered themselves 'a true heir to the Society of the $19^{\text {th }}$ Century', sharing the heritage and evangelicalism of the 'Parent Society' in England. ${ }^{8}$ It also distinguished itself from the other Anglican mission organisation in Australia, the Australian Board of Missions (ABM). The CMS was a democratic organisation governed by lay people, not the church establishment's bishops as in the ABM. It was also a Low Church evangelical society rather than High, so it emphasised personal conversion over sacramental styles of worship. This meant that the CMS could not always enjoy the support of bishops within whose diocese it operated (in the Northern Territory this was the Diocese of Carpentaria).

Following the CMS's failure at Wellington Valley (and the failure of many other similar missions), by the mid-nineteenth century much of white Australia suspected Aboriginal people could not be evangelised or 'civilised'.

Cole, Sharing in Mission, 7-8.

Johnstone, A History of the Church Missionary Society, 205-30.

Church Missionary Society of Australia, Decade, 6. 
The churches taught that anyone, no matter their race, could potentially convert to Christianity, but the rise of social-Darwinist theories - that some races prevailed over others due to their superior intellect, bodies or culture - challenged this doctrine. Perhaps some races were simply too backward to understand Christianity. At the same time, Aboriginal people were dying at such a rate that others imagined there would soon be none left to evangelise. There was a second wave of missionary activity in the latter half of the nineteenth century. The most famous of these were run by German Lutherans in Central Australia. They also established their most successful mission, Hermannsburg (1877-1982) near Alice Springs, one of few to survive into the era of twentieth-century missions. ${ }^{9}$

For Aboriginal people, life on these missions was, sometimes, a last resort in a dire situation. Missions brought some opportunities. There was the opportunity to gain access to new knowledge (especially to learn to read and write in English). They could also be a refuge from violent settlers. But the missions also operated with strict discipline and work regimes. They were generally under-resourced and located on the poorest farmland, residents (called 'inmates') lived in poverty. Although missionaries respected Aboriginal people as equally human, they held patronising views of Aboriginal cultures as underdeveloped and unsophisticated. Most focused on children, believing adults were too steeped in their traditions to change. This could be devastating for Aboriginal families, especially when missionaries forcibly removed children or used dormitories, as they did at Oenpelli.

After the failure of the nineteenth-century missions, missionary organisations and churches took a new approach in the early twentieth century. It was a national and Christian duty, they believed, to atone for the evils of colonisation. They looked, with hope, to Aboriginal people in remote parts of Australia who had little contact with Europeans. Perhaps in these isolated places, where Aboriginal culture still survived (white Australia had little understanding of how Aboriginal cultures had adapted to change in the southern parts of Australia, believing Aboriginal society and culture were destroyed), missions might have a chance at preventing the destruction experienced in the southern states. ${ }^{10}$

9 See Hill, Broken Song, Austin-Broos, Arrernte Present, Arrernte Past; Kenny, The Lamb Enters the Dreaming.

10 For histories of these missions see Rademaker, Found in Translation; Loos, White Christ Black Cross; Ganter, The Contest for Aboriginal Souls; Choo, Mission Girls; Emilsen, Fighting Spirit; Pybus, "We Grew Up This Place"; Morris, The Tiwi; Harris, One Blood. 


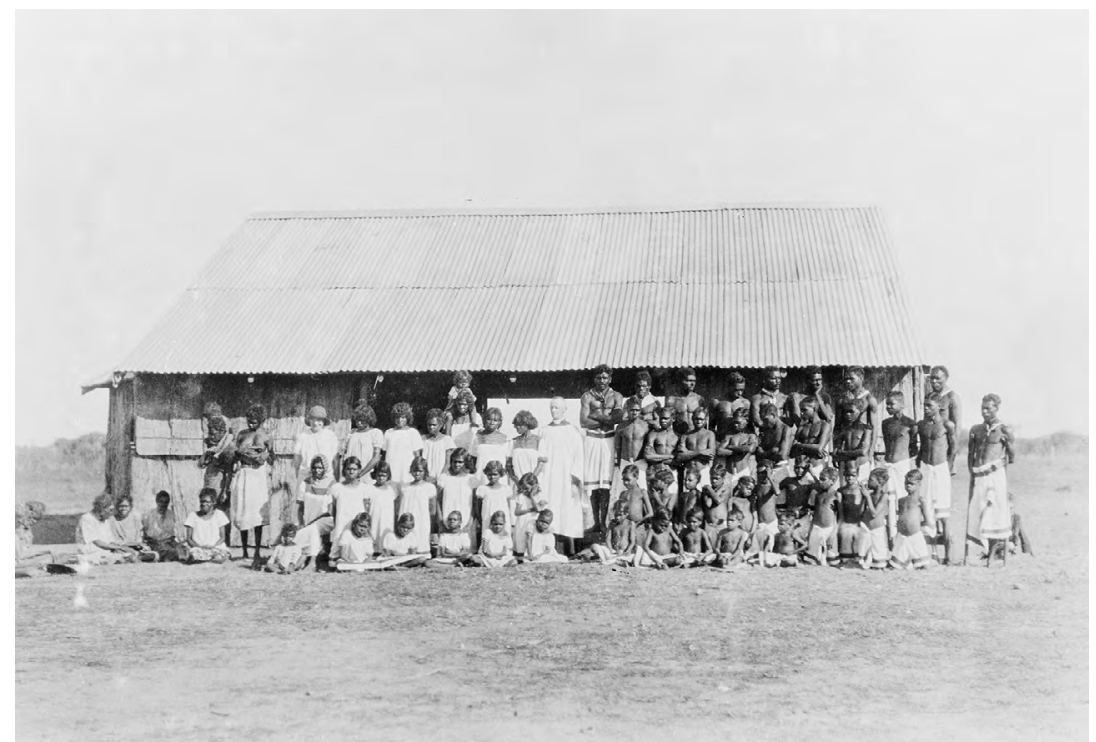

Figure 4.1: 'Native Congregation, Oenpelli Mission', 1928. Photograph by John Bleakley.

Source: National Archives of Australia (NAA A1200/L26057 Minister and congregation, Oenpelli Church of England Mission, Northern Territory, 1928).

The Victorian CMA started their work in Arnhem Land in 1908 with the Roper River mission. Soon after, the Commonwealth Government carved up the Northern Territory for the churches, giving the Anglicans, Catholics and Methodists 'spheres of influence' in which to operate missions, provide welfare and keep Aboriginal people away from towns. ${ }^{11}$ The Catholics had the west coast and Tiwi Islands, the Lutherans were in the centre, the Methodists took north and east Arnhem Land, the southeast went to the Anglicans. These spheres are still, implicitly, in operation today through the workings of faith-based social service agencies. With the assurance that its work would be protected as it expanded, the new united CMS of Australia and Tasmania began a mission on Groote Eylandt in 1921. When Oenpelli became available, it was natural it should go to the Methodist Church as it was close to their Goulburn Island mission and within their 'sphere'. But it was not an island. Thinking it would be too difficult to control who came and went, the Methodists rejected it, so did the Catholics. So it went to the Anglican CMS. ${ }^{12}$ 
The missionaries did not believe they came to destroy Aboriginal culture. The CMS articulated its approach in a 1931 policy document:

We deplore any method which tends to detribalise the natives and suggest:

a. A new method of approach to the Aborigines in their natural condition, that is by means of sporadic evangelism, in other words, a series of thrusts from strategically placed bases into the various tribal areas of Arnhem Land where the remnant of uncontaminated Aborigines of Australia is to be found. We feel that the stations at Oenpelli, Roper and Groote are so strategically situated, Mataranka being the convenient railhead.

b. We are convinced that this will mean ultimately a very considerable saving in expenditure; a more efficient and worthwhile evangelising of the Aborigines; and a more effective and statesmanlike staffing, grouping and interchanging of Missionaries, especially with the aid of the aeroplane which is now in the field. ${ }^{13}$

The CMS, at this stage, did not intend to institutionalise Aboriginal people entirely but to set up strategic bases for evangelism, from which Aboriginal people would come and go, but eventually settle. Aboriginal people would not be 'detribalised'. By that, they meant that Aboriginal authority and social structure would be respected. Of course, this was with the proviso that Aboriginal practices did not conflict with missionaries' moral views, leaving missionaries considerable scope to assert their own authority (and missionaries were the ones with guns). Missionaries particularly targeted Aboriginal 'superstition' (ceremony) and patterns of family life as 'immoral', not accepting that these were in fact integral to Aboriginal people's social structure. Nevertheless, this method, the CMS hoped, would be more effective in converting Aboriginal people than previous mission attempts. It would also be cheaper.

13 Minutes of a meeting of the Federal Council, 3-5 June 1931, ML MSS 6040/1. 
Tobacco was central to the whole enterprise. Missionaries had mixed feelings about it; they abstained themselves. But nothing worked better to attract Aboriginal people to the mission and induce them to work. The Aboriginal stockmen were essential workers, paid in small amounts of 'pocket money' and tobacco as well as sugar and tea (all addictive substances to varying degrees). Food was no incentive. The Aboriginal stockmen had no need for food; they knew how to live off the land. But the mission did provide meals for men, women and children as well as a general, smaller tobacco ration for those who worked at the mission in the garden or doing maintenance. ${ }^{14}$

Missionary women working as teachers and nurses and domestic staff formed the core of the mission staff. ${ }^{15}$ Apart from tobacco, medical aid and education were missions' other assets for attracting Aboriginal people. On proposing the establishment of Oenpelli mission in 1925, Alf Dyer suggested the necessary staff would consist of himself, his wife (a nurse) and 'a lady teacher'. ${ }^{16}$ The women's work was enormous. Female missionaries were constantly exhausted. Dyer, for example, reported that Florence Sherrin suffered a terrible string of maladies in her first 18 months: weight loss, whooping cough, malaria, pneumonia, a hearing impairment and stomach pains. ${ }^{17}$

\section{The missionaries}

Alf Dyer grew up in the suburbs of Melbourne. Born in Hawthorne in 1884, he left school at 13 and worked in the family-run hardware shop in Fitzroy. He said his family was not very religious. ${ }^{18}$ They found his piety amusing and teased him that he would grow up to be a priest. 'Zealous and enthusiastic', but not too bright was the general consensus on his character. ${ }^{19}$

14 Harris, My Story G.R. (Dick) Harris, 18, NTRS 1105.

15 For a history of missionary women in Australia, see Cruickshank and Grimshaw, White Women, Aboriginal Missions.

16 A. J. Dyer to Hinsby, 20 March 1925, ML MSS 6040/3.

17 A. J. Dyer to Ferrier, ML MSS 6039.

18 Dyer, Manuscript, 1, NTRS 693 part 1, Item 18.

19 Henry Mercer, 17 May 1911, ML MSS 6039/39. 


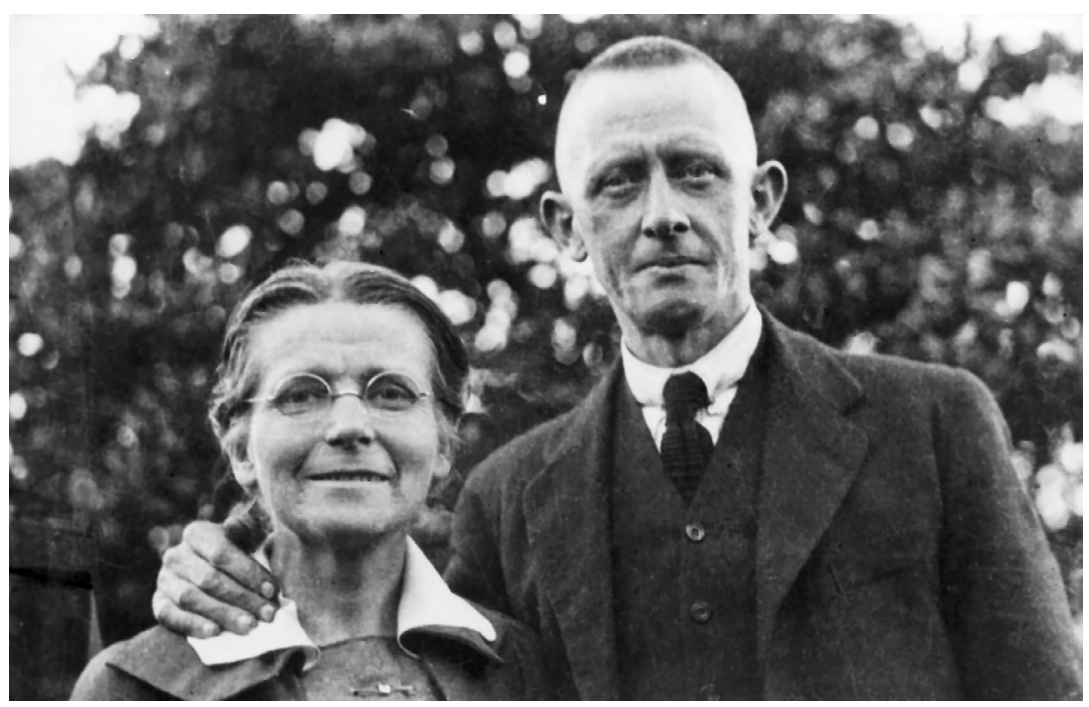

Figure 4.2: Mary and Alf Dyer (date unknown).

Source: Northern Territory Archives Service (NTRS 694 P1 Box 4e Item 681).

Dyer was convinced that God had called him to be a missionary to Africa, having been told in a vision in $1911 .^{20} \mathrm{He}$ was so convinced of his call, he offered to work as a missionary for half pay, if funds were an obstacle. But money was not the problem. Dyer failed his theological studies. ${ }^{21}$ He had no knowledge of any foreign language. ${ }^{22} \mathrm{He}$ eventually got the theological degree (he was 'not brilliant as a scholar' and only made it by 'perseverance in studying backed up by unceasing prayer' wrote his reference ${ }^{23}$ ), but, even after three abortive attempts, never passed ancient Greek. He was also single. ${ }^{24}$

The CMS was eager that more women should be posted on Aboriginal missions. The chair of the Roper River Committee even suggested to missionary Keith Langford Smith that the committee 'choose a suitable Christian girl and send her up to [him]' as a bride. Langford Smith refused, jesting that they should 'send a girl up on a thirty-day trial'. ${ }^{25}$ Dyer's application was rejected by the CMS in 1913, partly because of his

20 Dyer, Manuscript, 2, NTRS 693 part 1, Item 18.

21 Questions for Candidates, ML MSS 6039/35.

22 Questions for Candidates, ML MSS 6039/35.

23 John Stanley Robinson, 18 May 1911, ML MSS 6039/35.

24 Dyer, Manuscript, 5, NTRS 693 part 1, Item 18.

25 Keith Langford Smith, 'Marriage', Sky Pilot News, Jan-Feb 1981, NTRS 337/P1. 
lack of Greek, but mostly his lack of wife. That very year, the committee sent the woman he was later to marry - Mary Crome - in his place. For the CMS, missionary women had no need of husbands. The mission field needed single women, to teach and nurse. But missionary men needed wives to keep them in check from the 'temptations' of Aboriginal women. Single and without qualifications, Dyer had two strikes against him as a potential missionary.

Still, he was determined to make it. The CMS rejected Dyer from Africa but, eventually, the Victorian CMA invited him to go to the Roper River in March 1915. That the CMS chose to send a man with a notable lack of talent for language, and who they thought would not make it in Africa, indicates the regard they had for Aboriginal cultures and languages. Though the CMS accepted him, the Bishop of Carpentaria still had reservations. Dyer was not ordained as a deacon until 1927 as he had been directly blocked by the bishop when he hoped to be ordained in 1924. ${ }^{26}$ Eventually he became a priest, in 1928, meaning that, finally, he could preside over Holy Communion at the mission. Photographs of his early mission years suggest he had a fondness for pith helmets. Perhaps he imagined he was in Africa.

Dyer had some skills that suited him to the mission. His hardware store experience meant he knew everything about tools, but nothing about cattle. He was stubborn, eccentric and obsessive, prone to overwork. ${ }^{27}$ Other missionaries called him 'reckless'. A 'try anything once' attitude was the kinder way of putting it. ${ }^{28}$ Such was his enthusiasm that when he visited Groote Eylandt in 1921, he was eager to translate the chorus 'Jesus loves me' into Anindilyakwa. Pointing to his chest, he thought he had learned the word for 'me'. Only later did he learn he was singing 'Jesus loves my chest hair'. The Anindilyakwa camp must have enjoyed themselves. ${ }^{29}$ After his death, the preacher at his funeral commented on his 'strange personality', 'erratic, contradictory and elusive'. He was 'a very great man ... so strangely shackled and frustrated by his chronic incoherence of expression'. ${ }^{30}$ Alf was not a leader. But perhaps

26 Cole, Oenpelli Pioneer, 52.

27 Medical Form, ML MSS 6039.

28 Harris, My Story G.R. (Dick) Harris, 16, NTRS 1105.

29 Les Perriman Oral History, NTRS 226, TS 102.

30 Ralph Ogden quoted in Cole, Oenpelli Pioneer, 96. 
his wife Mary was. One missionary remembered that 'everyone thought [Mary] was the boss of Oenpelli', and locals joked that she 'wore the trousers'. ${ }^{31}$

Alf met Mary Catherine Crome at Roper River. She was 'Katie' to him. They were soon deeply in love. Crome was a strange woman herself. The subsequent superintendent of Oenpelli, Dick Harris, described her as almost completely without personality:

She reminded one of the one-time well known advertisement of Old Dutch Cleanser which pictured a starched, hooded Dutch woman cleansing dirt. ${ }^{32}$

Of course, those comments reveal as much about Harris's condescension to his female missionary colleagues as they do about Crome. But she was always working. A qualified nurse, on the mission she was also a seamstress, teacher, midwife and cook. Missionary Nell Harris described her as a strict, 'no nonsense' woman, but loving in her own way. ${ }^{33}$ She was born in Northcote, Victoria, in 1874 , so was a decade Dyer's senior. She began at Roper River mission when she was 39, full of enthusiasm for mission, although, until then, she had never met an Aboriginal person. Her diary reveals how she sank into depression during her first two years on the station. Missionary work was often lonely and monotonous for single women. It also reveals how she learned to find satisfaction in her work, growing less idealistic and more deeply committed to the mission.

Dyer and Crome courted secretly. Dating was improper. 'To walk out together or to kiss' was, in Dyer's melodramatic fashion, 'forbidden'. ${ }^{34}$ With the permission of CMS, they married in 1917. Their love letters are still in the archives. She missed him intensely when he travelled:

If you were only here now I would make you feel I love you it would be all I want humanly speaking just to feel that your arms were round me ... you would get so many of these $\operatorname{xxxxxxxxx.{}^{35}}$

31 Nell Harris in Harris, The Field Has Its Flowers, 21.

32 Harris, My Story G.R. (Dick) Harris, 17, NTRS 1105.

33 Harris, The Field Has Its Flowers, 19.

34 Dyer, Manuscript, NTRS 693 part 1, Item 18.

35 Mary Dyer to Alf Dyer, 1 February 1917, NTRS 693 part 1, Item 4. 


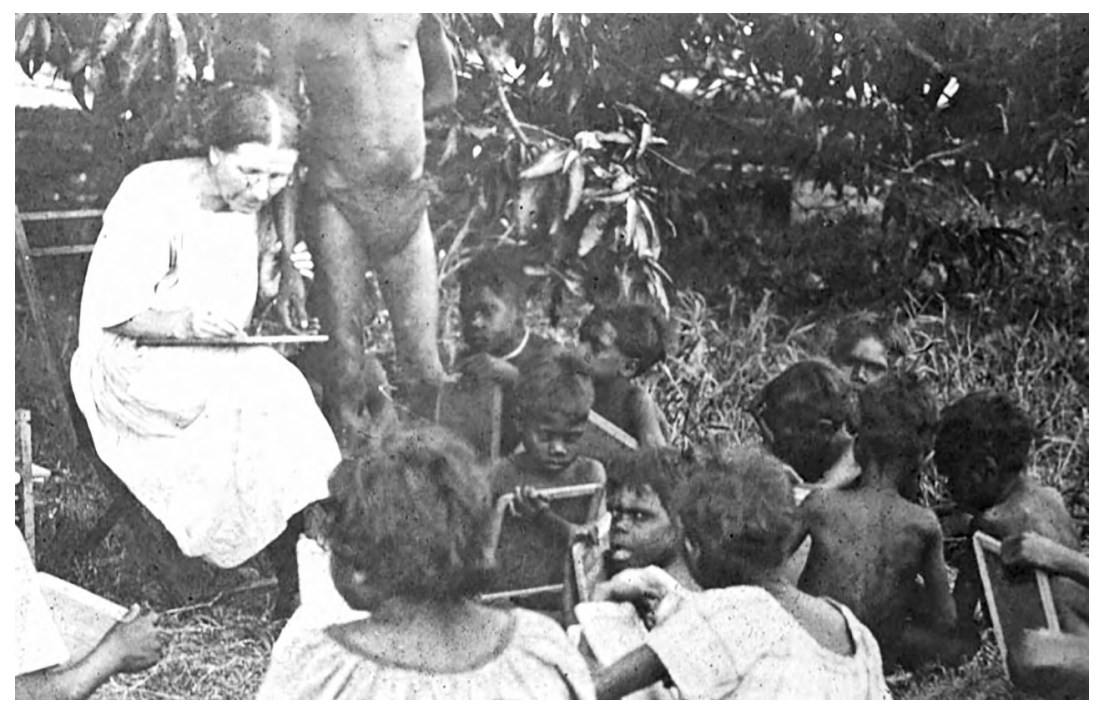

Figure 4.3: 'Mrs Dyer teaching in open air, Oenpelli' (date unknown).

Source: Item 431, Historical Oenpelli Slides, CMS, complied by K. Hart, A. Wilson and W. Kennedy, 1996.

Oenpelli station passed from the Campbells to the CMS on 18 June 1925. The Dyers, by then experienced missionaries, were appointed for the task. The happy missionary couple disembarked on the East Alligator River on 4 September and made their way to Oenpelli. First, they noticed its beauty. Surrounded by birds and flowers, nestled next to the billabong beneath red rocky hills, Gunbalanya is stunning. Assured by the Campbells that there were 'plenty of natives around the place', they began their work, optimistic about the future of this cattle station turned mission. By 1931, they were burnt out.

Alf Dyer's last hurrah was the Caledon Bay Peace Expedition in 1934. Together with a band of missionary men he went in 'peace' to persuade three Yolngu men accused of murder to face trial in Darwin. The supposedly 'peaceful' nature of the expedition was simply that it was not a massacre (which is what police had proposed). The missionaries were unarmed. But the episode ended in the death of one of the men Dhakiyarr Wirrpanda - in Darwin. Dhakiyarr disappeared soon after his release, most likely killed by police. 
The peace expedition was a publicity triumph for the CMS. But the Dyers' capacity was waning. In 1935, the Bishop of Carpentaria insisted that the Dyers must 'not return to the field'.$^{36}$ Alf had malaria and mouth ulcers. Mary was 'run down and tired'. ${ }^{37}$ According to Cole, both had some form of cancer. ${ }^{38}$ They retired from the CMS later that year, Dyer becoming parish minister in Guildford, Sydney. Ever committed to the mission and after decades of knowing no other work, this was not their choice but, in their words, 'owing to the Doctors' adverse report which forbids our return'. ${ }^{39}$

36 Minutes of the Oenpelli Committee of the NSW Branch of CMS, 15 April 1935, ML MSS $6040 / 4$.

37 R. Long to Hewett, 22 March 1935, ML MSS 6040/35.

38 Cole, Oenpelli Pioneer, 92.

39 Alf Dyer to Hewett, 29 June 1935, ML MSS 6040/35. 
This text is taken from The Bible in Buffalo Country: Oenpelli Mission 1925-1931, by Sally K. May, Laura Rademaker, Donna Nadjamerrek and Julie Narndal Gumurdul, published 2020 by ANU Press, The Australian National University, Canberra, Australia.

doi.org/10.22459/BBC.2020.04 